\title{
АЛГОРИТМ ХИРУРГИЧЕСКОГО ЛЕЧЕНИЯ БОЛЬНЫХ С РАССЕКАЮЩИМ ОСТЕОХОНДРИТОМ КОЛЕННОГО СУСТАВА
}

\author{
К. А. Егиазарян, Г. Д. Лазишвили凶, И. В. Храменкова, М. А. Шпак, Д. А. Бадриев \\ Кафедра травматологии, ортопедии и военно-полевой хирургии, \\ Российкий национальный исследовательский медицинский университет имени Н. И. Пирогова
}

\begin{abstract}
Наиболее часто рассекающий остеохондрит коленного сустава, или болезнь Кёнига, встречается у активных молодых людей, занятых физическим трудом, спортом, т. е. представителей социально активной прослойки населения. Несмотря на разнообразие современных методик хирургического лечения болезни, остается много спорных вопросов по их применению, отсутствует оптимальный подход и ограничена доступность качественных биоматериалов, требующихся при вмешательстве. Проведенный анализ результатов лечения пациентов за несколько лет показал высокую актуальность и необходимость решения многих вопросов этой проблемы. В работе представлен алгоритм хирургического лечения рассекающего остеохондрита коленного сустава. Обоснованы показания к оперативному вмешательству, предложены оптимальные способы коррекции локальных дефектов хряща в зависимости от стадии его поражения и возраста пациента, даны рекомендации, основанные на практическом опыте авторов.
\end{abstract}

Ключевые слова: локальные десекты хряща, коленный сустав, рассекающий остеохондрит, болезнь Кёнига, костно-хрящевой десект, коллагеновая матрица, «мозаичная» костно-хрящевая аутотрансплантация

$凶$ Для корреспонденции: Гурам Давидович Лазишвили ул. Островитянова, д. 1, г. Москва, 117997; guramlaz@gmail.com

Статья получена: 16.05.18 Статья принята к печати: 23.05.18 DOI: $10.24075 /$ vrgmu.2018.020

\section{KNEE OSTEOCHONDRITIS DESICCANS: SURGERY ALGORITHM}

\author{
Egiazaryan KA, Lazishvili GD凶, Hramenkova IV, Shpak MA, Badriev DA
}

Department of Traumatology, Orthopedics and Military Field Surgery,

Pirogov Russian National Research Medical University, Moscow

\begin{abstract}
Knee osteochondritis desiccans, or Koenig's disease, is commonly found in active young people engaged in manual labor, sports etc., i.e. socially active population. Today, we have a good number of surgical method to treatment of this disorder; however, there is still much controversy about their application, and no single approach is considered to be the optimal one. Plus, high-quality biomaterials required for the intervention are sometimes unavailable. The analysis of the results of treatment of patients (spanning several years) proved urgency of the problem and highlighted the necessity to solve a number of related issues. This paper presents the algorithm of surgical treatment of knee osteochondritis desiccans. We have provided surgery validation criteria, suggested optimal methods of correction of local cartilage defects (depending on the degree of damage and patient's age) and outlined some recommendations based on our practical experience.
\end{abstract}

Keywords: local cartilage defects, knee joint, osteochondritis dissecans, Koenig's disease, osteochondral defect, collagen scaffold, mosaic plastic

$\square$ Correspondence should be addressed: Guram Davidovich Lazishvili

Ostrovityanova 1, Moscow, 117997; guramlaz@gmail.com

Received: 16.05 .18 Accepted: 23.05.18

DOI: $10.24075 /$ brsmu.2018.020

Лечение патологии внутрисуставного гиалинового хряща является актуальной проблемой в ортопедии, а хирургическая коррекция локальных хрящевых дефектов на сегодняшний день одна из труднейших задач для врача.

Частота встречаемости рассекающего остеохондрита мыщелков бедренных костей, или болезни Кёнига, среди всех заболеваний коленного сустава достигает $2 \%$. Патология распространена в основном в возрастных группах 11-13 и 20-40 лет.

Ежегодно в Европе проводится более 300 тыс. операций по коррекции локальных внутрисуставных хрящевых десектов коленного сустава[1]. Многиеприменяемые ранее методы хирургического лечения заболевания (рефиксация хрящевой пластины, туннелизация субхондральной кости и др.) довольно устарели и оказались малоэффективными.

В 80-85\% случаев зона рассекающего остеохондрита находится в области медиального мыщелка бедра, в 1020\% случаев - в области латерального мыщелка бедра, в 4\% случаев - на суставной поверхности надколенника и в 0,5-0,7\% - в области межмыщелковой борозды бедренной кости. В 14-24\% случаев болезнь Кёнига носит двусторонний характер [2].

Не до конца понятны причины, вызывающие поражение хряща при рассекающем остеохондрите. Среди них могут быть конституциональные и генетические факторы, ишемия, травма, болезнь перегрузки, нарушения процесса оссисикации и др [3]. Возможно, что в основе патогенеза болезни Кёнига лежат ишемия и локальный некроз субхондральной кости с распространением на хрящевую ткань. Прогрессируя, рассекающий остеохондрит приводит к отделению нежизнеспособного субхондрального фрагмента и выпадению его в полость сустава.

Несмотря на разнообразие предложенных методик хирургического лечения болезни Кёнига, в том числе с применением результатов развития биотехнологии, остается много спорных вопросов [4-8]. Не прекращаются дискуссии по поводу необходимости одномоментного выполнения и костной, и хрящевой пластики. Отсутствие 
единого мнения и стандартов создает сложности в обосновании выбора тактики лечения больных с болезнью Кёнига, особенно у пациентов юношеского возраста с незакрытой зоной роста.

К сожалению, в настоящее время спектр возможностей отечественных хирургов при лечении больных с рассекающим остеохондритом крайне ограничен. Это связано с недоступностью широкого применения многих возможностей современных био- и клеточных технологий. Отсутствие отечественных аналогов и высокая стоимость импортных биоматериалов определяют экономическую нецелесообразность их использования в отечественных клиниках.

Анализ отдаленных исходов лечения больных с рассекающим остеохондритом коленного сустава по методике костно-хрящевой аутотрансплантации («мозаичной» хондропластики), традиционно применяемой в настоящее время во многих отечественных клиниках, показал ее недостатки: частую невозможность полноценного восстановления конгруэнтности суставных поверхностей, как и самого дефекта; возникновение проблем в области патело-феморального сочленения. Одна из основных причин затруднений, возникающих интраоперационно при лечении обширных костнохрящевых дефектов мыщелков бедренных костей, - это десицит пластического материала.

В данной работе представлены обоснование выбора и алгоритм оптимальной тактики хирургического лечения рассекающего остеохондрита мыщелков бедренных костей в зависимости от стадии поражения хряща.

\section{Дизайн исследования}

Для обоснования выбора и создания алгоритма оптимальной тактики лечения был проведен анализ результатов лечения 184 больных с разнообразными хроническими полнослойными локальными хрящевыми и костно-хрящевыми повреждениями коленного сустава, прооперированных за период с 1995 по 2017 гг. в ГКБ № 1 им. Н. И. Пирогова.

Всех пациентов разделили на основную и контрольную группы. Пациентам первой группы в составе 86 человек были применены современные методики хирургической коррекции локальных дефектов хряща (моно или «мозаичная» костно-хрящевая ауто- или аллотрансплантация, технология индуцированного на матрице аутохондрогенеза, или технология AMIC, - имплантация коллагеновой матрицы с костной пластикой и без нее) [1, 2].

Контрольную группу составили 98 пациентов, прошедшие лечение по старым методикам коррекции локальных десектов хряща (абразивная хондропластика, формирование микропереломов субхондральной кости, туннелизация) [2-5, 6].

Давность заболевания оценивалась со слов больных во время сбора анамнеза, а именно с момента появления первых жалоб до постановки диагноза.

В качестве методов исследования и оценки результатов применяли клинико-функциональное обследование, магнитнорезонансную томографию (МРТ) и мультиспиральную компьютерную томографию (МСКТ), в пред- и послеоперационном периодах выполняли сравнительную оценку шкал: фризической активности ICRS (ICRS Международное общество по восстановлению хряща), ВАШ (визуально-аналоговую шкала) и функционального состояния коленного сустава WOMAC [2].
Для исследования и оценки результатов при анализе выполненных компьютерных томограмм коленного сустава использовали шкалу Хаунссилда. Оценку изображений, полученных при MPT, делали по шкале MOCART [9-11].

Критерии включения в исследование: мужчины и женщины от 15 до 60 лет (средний возраст $40 \pm$ 1,6 лет), наличие хронических полнослойных хрящевых дефектов коленного сустава 3-й и 4-й стадии по классификации ICRS.

Критерии исключения: мужчины и женщины иного возраста, наличие свежих повреждений хряща, неполнослойный характер дефекта (1-я и 2-я стадии по классификации ICRS).

Отдаленные результат лечения (до 8 лет) были изучены нами у 70 больных $(81,4 \%)$ основной группы и 78 больных $(79,6 \%)$ контрольной группы. Результаты изучены не у всех пациентов по причине недоступности ряда больных для контакта и маленьких сроков, прошедших с момента операции.

Ниже представлен разработанный нами алгоритм хирургического лечения больных с рассекающим остеохондритом коленного сустава, сформулированным нами на основании выполненного исследования и применяемый в нашей клинике.

\section{Хирургическая коррекция рассекающего остеохондрита коленного сустава}

\section{1. Пациенты с незакрытой зоной роста}

В настоящее время для отечественных клиник доступно проведение нескольких вариантов хирургической коррекции локальных костно-хрящевых дефектов мыщелков бедренной кости, межмыщелковой борозды, надколенника.

Выполнение костно-хрящевой трансплантации пациентов юношеского возраста с незакрытой зоной роста, на наш взгляд, нецелесообразно. Так же бесперспективна и рефиксация отделившейся некротизированной костнохрящевой пластины. Имплантация коллагеновой матрицы (технология AMIC) на некротизированную субхондральную кость не приведет к ее регенерации. Нами верифицировано прогрессирующее разрушение субхондральной кости при применении технологии АМIC без костной пластики. Более подробно об этой технологии см. ниже.

Таким образом, методом выбора у пациентов данной возрастной группы остается методика создания сверлом тунеллей в субхондральной кости, основанная на репаративной способности мезенхимальных стволовых клеток, поступающих через выполненные отверстия [12]. В последние годы данную манипуляцию мы выполняем артроскопическим способом сверлом диаметром 3,5 мм с треугольной заточкой на конце и ограничителем глубины погружения в кость до 15 мм (рис. 1).

\section{2. Пациенты с закрытой зоной роста}

\section{«Мозаичная» костно-хрящевая аутотрансплантация}

У пациентов с закрытой зоной роста, у которых площадь костно-хрящевого дефекта не превышает 10 см² $^{2}$ мы рекомендуем отдавать предпочтение «мозаичной» костнохрящевой аутотрансплантации.

Важно еще на этапе предоперационного планирования определить возможность проведения полноценной костно-хрящевой аутотрансплантации артроскопическим 
способом. Далеко не всегда удается артроскопически произвести полноценный забор донорских столбиковтрансплантатов, «мозаичную» пластику и восстановление конгруэнтности суставной поверхности [13, 14]. Как правило, это связано с ограниченными возможностями манипулирования в суставе инструментами через артроскопические доступы. В таких случаях более правильно выполнять «Мозаичную» хондропластику открытым или мини-инвазивным способом [15].

Необходимо остановиться на одной важной детали в технике выполнения операции: на расположении трансплантатов. Для полноценного хондрогенеза и регенерации хрящевой поверхности дефекта, трансплантаты необходимо располагать максимально близко друг к другу, практически вплотную или с небольшим «нахлестом» на соседний столбик-трансплантат.

Через 12 месяцев после оперативного лечения на выполненных контрольных компьютерных томограммах отмечалась хорошая костная и хрящевая регенерация в зоне «мозаичной» пластики (рис. 2).

В случаях, когда площадь костно-хрящевого дефекта превышала 10 см², до начала 2017 г. мы отдавали предпочтение «мозаичной» костно-хрящевой аллотрансплантации. В качестве донорского алломатериала использовали лиофилизированные консервированные мыщелки бедренных костей. Стерилизацию алломатериалов проводили гамма-излучением. Техника операции и расположение столбиков-трансплантатов были аналогичными, как и при костно-хрящевой аутотрансплантации (рис. 3).

Такая методика операции, на наш взгляд, имеет ряд преимуществ. Отсутствие необходимости забора аутологичных донорских столбиков-трансплантатов из боковых отделов коленного сустава значительно снижает время выполнения и травматичность операции. При небольших по площади поражениях мыщелка эту операцию можно выполнять и артроскопическим способом. Не возникает проблем с дефицитом пластического материала,
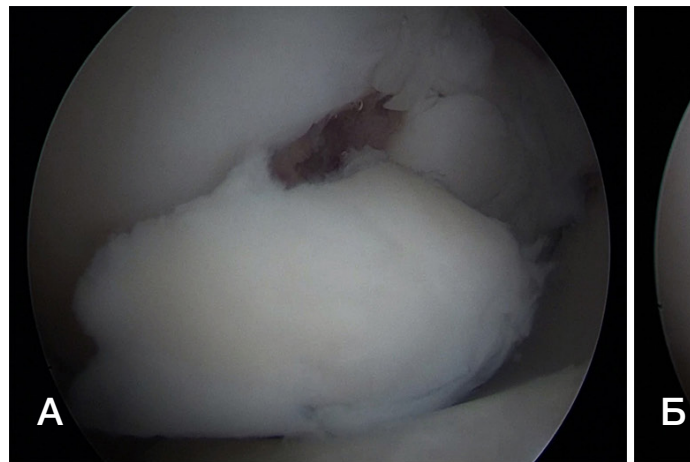

что позволяет выполнить полноценную пластику костнохрящевого десекта с использованием аллотрансплантатов разного диаметра. Нет необходимости использовать биоматериалы, что значительно снижает стоимость операции. Эту технологию можно использовать при любой локализации костно-хрящевого дефекта в коленном суставе и не только в нем [16].

В настоящее время мы широко применяем комбинированную (ауто- и алло-) «мозаичную» костнохрящевую трансплантацию (рис. 4). Анализ ее исходов показал более качественную регенерацию субхондральной кости и хрящевой поверхности мыщелка бедра.

Представим несколько наших рекомендаций по использованию методики костно-хрящевой трансплантации:

- для полноценной пластики костно-хрящевого десекта целесообразно использовать трансплантать диаметром не менее 5-6 мм;

- для достижения полноценной регенерации необходимо столбики-трансплантаты располагать вплотную друг к другу или с небольшим «нахлёстом» с соседним столбиком трансплантатом;

- при костно-хрящевом десекте площадью более

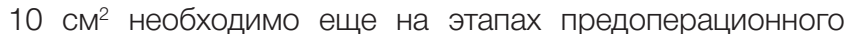
планирования адекватно оценить возможность полноценной пластики дефекта. При риске дефицита аутопластического материала оптимально выполнять комбинированную ауто- и аллопластику дефекта.

\section{Техника формирования микропереломов} в субхондральной кости по Стедману

C 2002 по 2005 годы при 3-й стадии локального поражения хряща контактных зон мыщелков бедренной кости, не превышающего 5 см², мы широко использовали технику формирования микропереломов в субхондральной кости по Стедману $[2,4,5]$. Методика основана на стимуляции хондрогенеза стволовыми клетками, полученными через
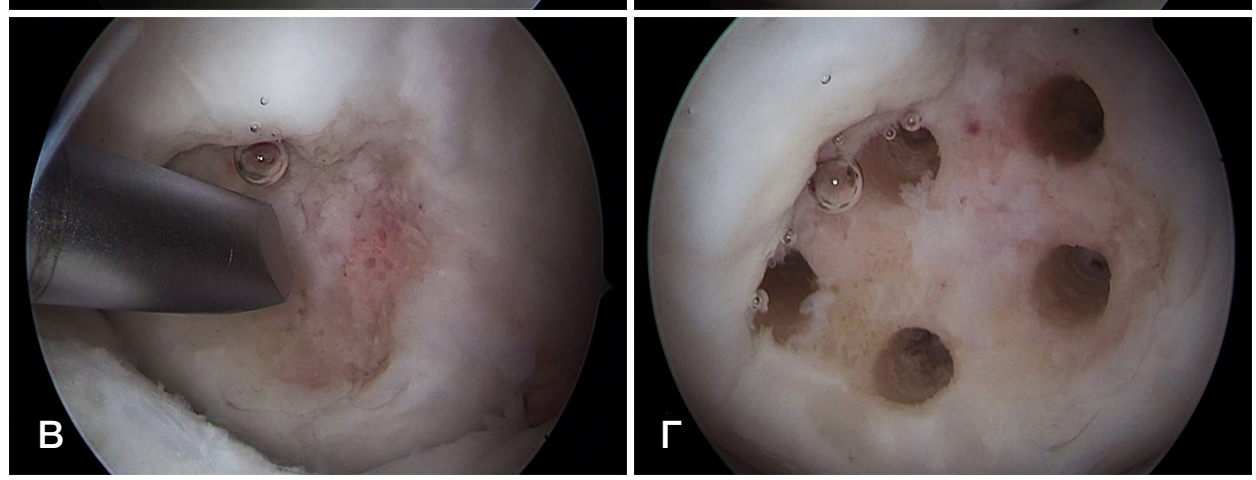

Рис. 1. А. Артроскопическая картина отделившейся некротизированной хрящевой пластины. Б. Артроскопический вид костно-хрящевого десекта после удаления некротизированной пластины. В. Формирование туннелизационных отверстий в субхондральной кости. Г. Субхондральная кость после туннелизации 
сформированные отверстия. Анализ результатов этих операций показал бесперспективность их выполнения в связи с отсутствием желаемого эффекта, в частности восстановления хрящевой ткани на пораженном участке. Отрицательные исходы операций еще раз доказывают, что для нормального хондрогенеза стволовые клетки должны быть фиксированы в зоне дефекта хряща в виде суперсгустка.

Методика индуцированного на матрице аутохондрогенеза (AMIC)

В последние годы для лечения полнослойных дефектов хряща все большую популярность приобретает методика индуцированного на матрице аутохондрогенеза (AMIC) (рис. 5). В ее основе лежит описанная выше репаративная способность мезенхимальных стволовых клеток, выходящих
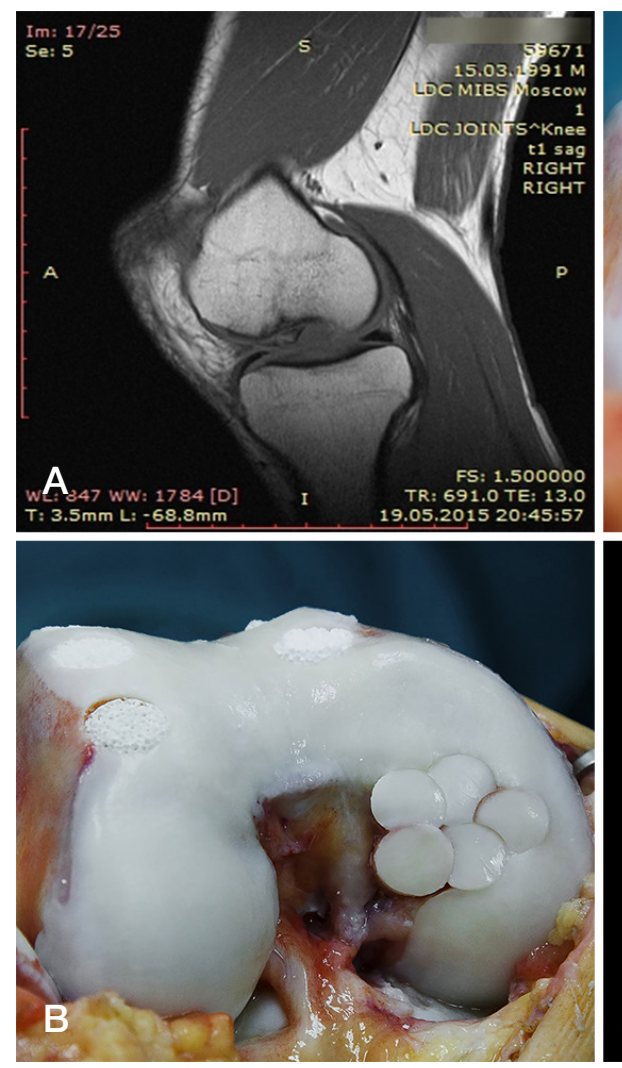

в полость сустава через отверстия, выполненные сверлом в субхондральной кости [17-22].

В результате туннелизации образуется «суперсгусток» из цитокинов и стволовых клеток красного костного мозга, который благодаря имплантации на костно-хрящевой дефект матрицы становится стабильным, стимулируя восстановление костной и формирование хрящеподобной ткани $[23,24]$.

Преимущества технологии индуцированного на матрице аутохондрогенеза очевидны: малоинвазивность процедуры; возможность восстановления крупных дефектов хряща; простота хирургической техники; доказанная эффективность: у пациентов снижалась интенсивность болевого синдрома, а в ряде случаев он полностью проходил и восстанавливалась функция коленного сустава, что в результате увеличивало удовлетворенность больных результатами лечения.
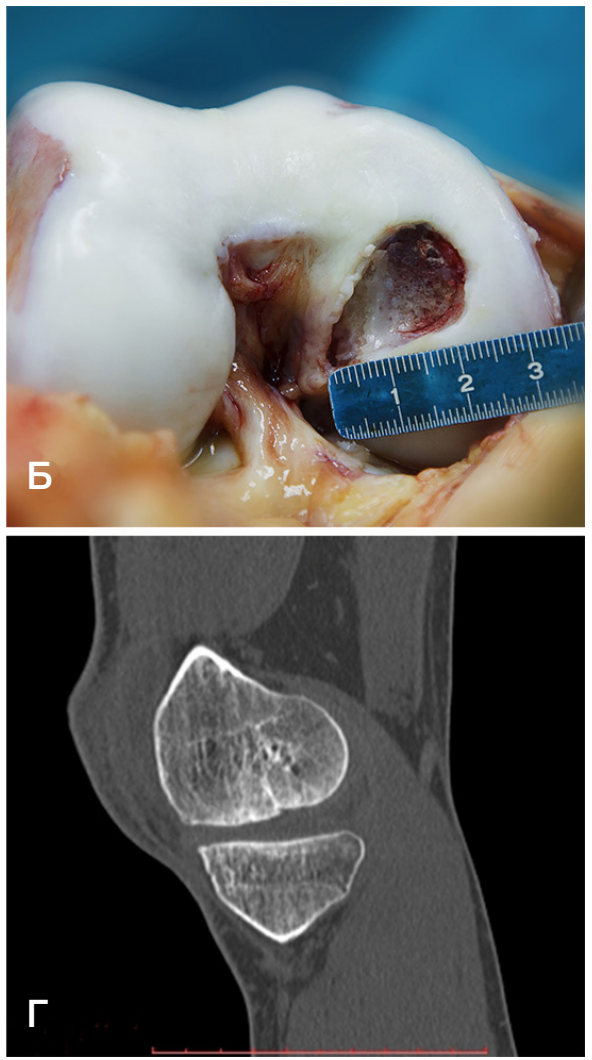

Рис. 2. А. МРТ-картина рассекающего остеохондрита медиального мыщелка бедренной кости. Б. Форма и размеры дефекта мыщелка после его санации. В. Результат «мозаичной» костно-хрящевой аутопластики. Донорские отверстия заполнены биокомпозитной костью. Г. МСКТ картина через 12 месяцев после операции. Отмечаются хорошая костная и хрящевая регенерация в зоне «мозаичной» пластики
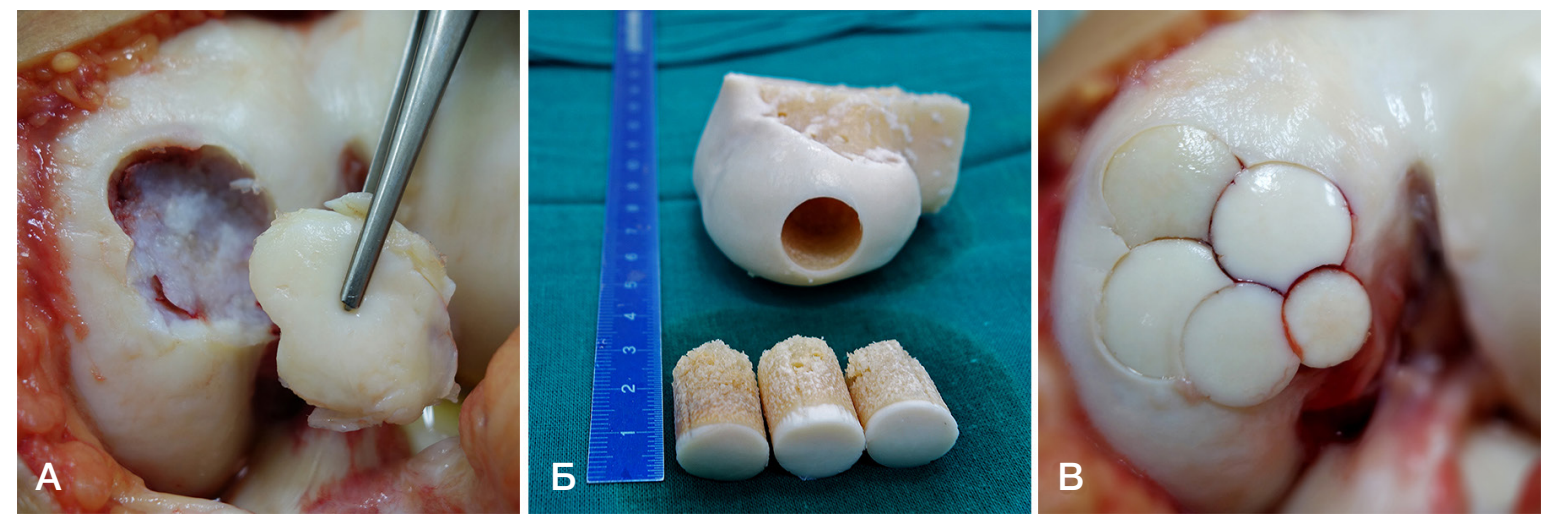

Рис. 3. А. Костно-хрящевой дефект медиального мыщелка бедренной кости (болезнь Кёнига). Б. Аллогенный лиофилизированный мыщелок бедренной кости и цилиндрические донорские столбики трансплантаты. В. Результат «мозаичной» костно-хрящевой аллопластики 
На сегодняшний день для восстановления хрящевой ткани коллагеновая матрица является ведущим биологическим материалом, положительно влияющим на дисфференцировку стволовых клеток и хондрогенез.

Операцию считаем показанной при полнослойных десектах гиалинового хряща, без поражения субхондральной кости (3-я стадия по классификации ICRS). Обязательные условия для проведения - наличие здорового гиалинового хряща, окружающего дефект, жизнеспособной субхондральной кости и неизмененной механической оси нижней конечности.

Противопоказаниями к операции считаем наличие множественных хрящевых десектов, в том числе «целующихся повреждений»; распространенный остеоартроз коленного сустава; системные аутоиммунные заболевания; обусловленную повреждениями связок и менисков нестабильность коленного сустава; вальгусную или варусную десормацию голени, требующую выполнения корригирующих операций; аллергические реакции на коллаген.

Особенно пристальное внимание следует уделять состоянию субхондральной кости, выраженный склероз которой указывает на ее нежизнеспособность. Считаем необходимым выполнение санации нежизнеспособной костидоздоровыхкровоточащихслоевскостнойпластикой десекта. Отсутствие «кровяной росы» после выполнения туннелизации субхондральной кости свидетельствует о нежизнеспособности, что должно насторожить хирурга. В таких случаях имплантация коллагеновой матрицы без костной пластики бесперспективна.

Представим несколько наших рекомендаций, сделанных на основании анализа отдаленных исходов применения

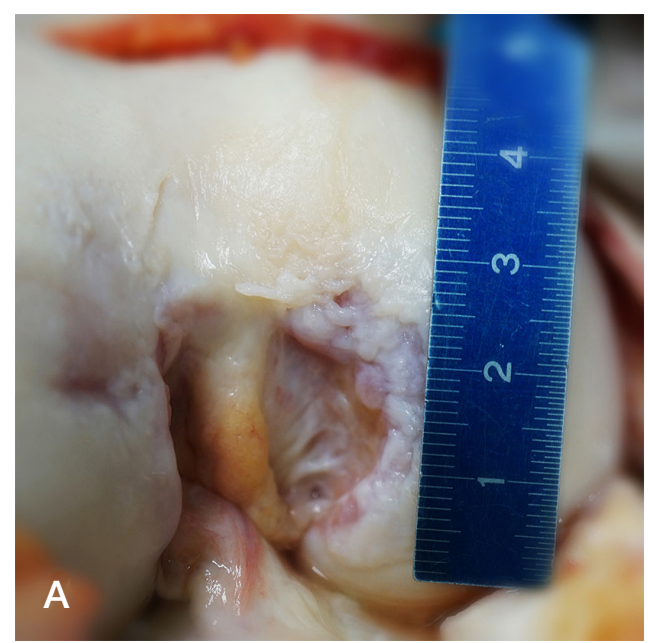

технологии индуцированного на матрице аутохондрогенеза у наших пациентов:

- имплантация коллагеновой матрицы показана только при здоровой и стабильной субхондральной кости

- при глубоких (более 5 мм) локальных поражениях субхондральной кости показана костная пластика костнохрящевого дефекта;

- одномоментная пластика костно-хрящевого десекта биокомпозитной костью и имплантация матрицы бесперспективны;

- при предоперационном планировании необходимо учитывать уровень физической активности пациентов. K сожалению, технология индуцированного на матрице аутохондрогенеза и спорт высших достижений несовместимы.

\section{ЗАКЛЮЧЕНИЕ}

Анализ результатов лечения пациентов, оперированных в нашей клинике, доступных материалов, данных литературы и технических возможностей позволил нам оптимизировать алгоритм хирургического лечения пациентов с рассекающим остеохондритом коленного сустава и сделать определенные выводы: 1) у пациентов с незакрытой зоной роста показано удаление нежизнеспособной хрящевой пластины, санация костнохрящевого дефекта и туннелизация субхондральной кости; 2) при полнослойных локальных дефектах хряща без поражения субхондральной кости оптимальна технология индуцированного на матрице аутохондрогенеза; 3) при локальных остеохондральных дефектах площадью менее

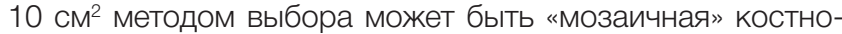
хрящевая аутотрансплантация; 4) при локальных костно-

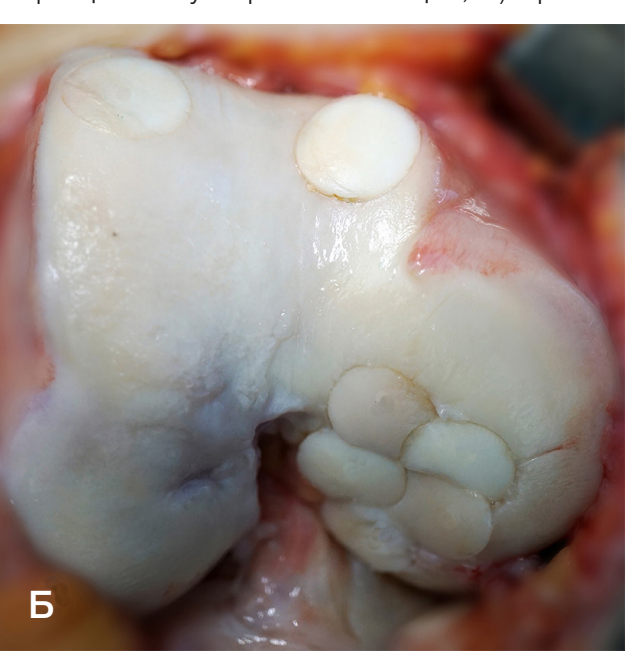

Рис. 4. А. Форма и размеры костно-хрящевого дефекта медиального мыщелка бедра при болезни Кёнига. Б. Результат комбинированной костно-хрящевой трансплантации. А 一 ауто, Д - донор алло
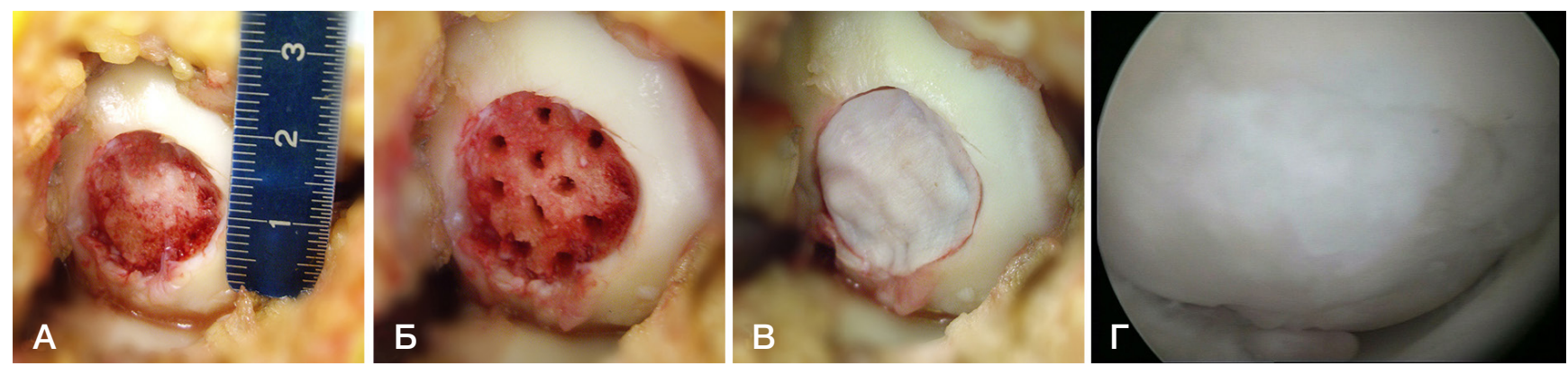

Рис. 5. А. Форма и размеры десекта хряща медиального мыщелка бедра после его санации. Б. Субхондральная кость после туннелизации. В. Имплантация коллагеновой матрицы. Г. Артроскопическая картина через 1,4 года: дефект мыщелка полностью закрыт стабильной хрящевой тканью 
хрящевых десектах площадью 10-15 см² целесообразно выполнение комбинированной «мозаичной» костнохрящевой трансплантации.

В заключение стоит отметить, что объективный анализ ошибок и осложнений во многом позволил нам изменить сложившиеся стереотипы в отношении выбора тактики лечения локальныххрящевых и костно-хрящевыхдесектов мыщелков бедра, отказаться от ряда бесперспективных технологий, усовершенствовать методики операции. Несмотря на это, в проблеме хирургического лечения рассекающего остеохондрита коленного осустава остается много спорных вопросов.

\section{Литература}

1. Anders $\mathrm{S}$, Wiech $\mathrm{O}$, Schaumburger J, et al. Autologus Matrix induced chondrogenesis (AMIC) for focal chondal defects of the knee - first results. J Bone Joint Surg Br. 2009; 91 (Suppl.1): 83-7.

2. Маланин Д. А., Писарев В. Б., Новочадов В. В. Восстановление повреждений хряща в коленном суставе. Экспериментальные и клинические аспекты. Волгоград: Волгоградское научное издательство; 2010. 455 с.

3. Alford JW, Cole BJ. Cartilage restoration, part 1: basic science, historical perspective, patient evaluation and treatment options. Am J Sports Med. 2005; 33 (2): 295-306.

4. Solheim E, Hegna J, Inderhaug E, Oyen J, Harlem T, Strand T. Results at 10-14 years after microfracture treatment of articular cartilage defects in the knee. Knee Surg Sports Traumatol Arthroscop. 2016; 24 (5): 1587-93.

5. Xing L, Jiang $Y$, Gui J, Lu Y, et al. Microfracture combined with osteochondral paste implantation was more effective than microfracture alone for full-thickness cartilage repair. Knee Surg Sports Traumatol Arthroscop. 2013; 21 (8): 1770-76.

6. Laupattarakasem W, Laopaiboon M, Laupattarakasem $P$, Sumananont C. Arthroscopic debridement for knee osteoarthritis (Review). Cochrane Database Syst Rev. 2008; Issue 1. Art. No.: CD005118. DOI: 10.1002/14651858.CD005118.pub2.

7. Стадников А. А., Кавалерский Г. М., Архипов С. В., Павлов В. П., Макаров С. А., Макаров М.А. и др. Новые методы хирургического лечения десектов гиалинового хряща коленного сустава у больных с гонартрозом. Научно практическая ревматология. 2009; 3: 90-3

8. Tratting S, Ba-Ssalamah A, Pinker K, Plank C, Vescei V, Marlovits S. Magnetic Resonance Imaging. 2005; 23 (7): 779-87.

9. Ковальчук В. Н. Классификация поврежденного хряща коленного сустава. Лучевая диагностика, лучевая терапия. 2012; 1: 99-106

10. Головаха М. Л., Лоскутов А. Е., Егоров В.Ф. Корреляция данных магнитно- резонансной томографии и артроскопии при травматических повреждениях коленного сустава. Практикующему врачу. 2011; 12 (2): 99-105.

11. ЛазишвилиГ.Д., Затикян В. Р., Шукюр-Заде Э. Р., Корнаев А. С., Акматалиев К. И., Данилов М. А. Актуальные вопрось хондропластики. Вестник РГМУ. 2013; 3: 13-17.

12. Малышев Е. Е., Королев С. Б., Павлов Д. В., Кувшинов С. Г. Костно-хрящевая аутотранплантация обширного посттравматического дефекта проксимального отдела большеберцовой кости. Современные технологии в

\section{References}

1. Anders S, Wiech O, Schaumburger J, et al. Autologus Matrix induced chondrogenesis (AMIC) for focal chondal defects of the knee - first results. J Bone Joint Surg Br. 2009; 91 (Suppl.1): 83-7.

2. Malanin DA, Pisarev VB, Novochadov V. Vosstanovlenie povregdeniy chryasha $\vee$ kolennom sustave. Eksperimental'nye i klinicheskie aspekty. Volgograd: Volgogradskoe nauchnoe izdatel'stvo; 2010. $455 \mathrm{c}$.

3. Alford JW, Cole BJ. Cartilage restoration, part 1: basic science, historical perspective, patient evaluation and treatment options. медицине. 2014: 6 (2): 142-7.

13. Котельников Г. П., Ларцев Ю. В., Кудашев Д. С., ЗуевРатников С. Д., Шорин И. С. Мозаичная хондропластика в лечении больных с деструктивно-дистрофическими и посттравматическими поражениями гиалинового хряща в коленном суставе - экспериментальные и клинические аспекты. Фундаментальные исследования. Медицинские науки. 2013; 9: 252-5.

14. Закирова А. Р. Артроскопическое лечение хрящевых дефектов коленного сустава. М.: 2010.

15. Caldwell PE, Shelton WR. Indications for allografts. Orthop Clin North Am. 2005; 36 (4): 459-67.

16. Sadlik B, Wiewiorski M. Implantation of a collagen matrix for an AMIC repair during dry arthroscopy. Knee Surg Sports Traumatol Arthrosc. 2015; 23: 2349-52.

17. Gille J, Schuseil E, Wimmer J, et al. Mid-term results of autologus matrix-indused chondrogenesis for treatment of focal cartilage defects in the knee. Knee Surg Sports Traumatol Arthrosc. 2010; 18: 1456. https://doi.org/10.1007/s00167-010-1042-3.

18. Pascarella A, Ciatti R, Pascarella F, et al. Treatment of articular cartilage lesions of the knee joint using a modified AMIC technique. Knee Surg Sports Traumatol. Arthrosc. 2010; 18: 509-13.

19. Anders S, Wiech O, Schaumburger J, et al. Autologus Matrix induced chondrogenesis (AMIC) for focal chondal defects of the knee - first results. J Bone Jt Surg (Brit.). 2009; 91 (suppl.1): 834

20. Hangody L, Vasarhelyi G, Hangody LR, et al. Autologus osteochondral grafting technique and long-term results. Injury. 2008; 39 (suppl.1): 32-9.

21. Steinwachs M, Kreuz PC. Autologus chondrocyte implantation in chondral defects of the knee with a type I/III collagen membrane: A prospective study with a 3-year follow-up. Arthroscopy. 2007; 23: 381-7.

22. Гаркави А. В., Блоков М. Ю. Артроскопическая хондропластика локальных хрящевых десектов коленного сустава с использованием коллагеновой мембрань CHONDRO-GIDE. Кафедра травматологии и ортопедии. 2015; 3 (15): 4-7.

23. Jacob RP. AMIC technique for cartilage repair, a single-step surgical intervention as compared to other methods. Eur Cell Mater. 2006; 12 (suppl.1): 26-32.

24. Kramer J, Bohrnsen F, Lindner U, et al. In vivo matrix-guided human mesenchymal stem cells. Cell Mol Life Sci. 2006; 63 (5): $616-26$

Am J Sports Med. 2005; 33 (2): 295-306.

4. Solheim E, Hegna J, Inderhaug E, Oyen J, Harlem T, Strand T. Results at 10-14 years after microfracture treatment of articular cartilage defects in the knee. Knee Surg Sports Traumatol Arthroscop. 2016; 24 (5): 1587-93.

5. Xing L, Jiang $Y$, Gui J, Lu $Y$, et al. Microfracture combined with osteochondral paste implantation was more effective than microfracture alone for full-thickness cartilage repair. Knee Surg Sports Traumatol Arthroscop. 2013; 21 (8): 1770-76.

6. Laupattarakasem $\mathrm{W}$, Laopaiboon $\mathrm{M}$, Laupattarakasem $\mathrm{P}$, 
Sumananont C. Arthroscopic debridement for knee osteoarthritis (Review). Cochrane Database Syst Rev. 2008; Issue 1. Art. No.: CD005118. DOI: 10.1002/14651858.CD005118.pub2.

7. Stadnikov AA, Kavalerskiy GM, Arhipov SV, Pavlov VP, Makarov SA, Makarov MA, i dr. Novye metody hirurgicheskogo lecheniya defectov gialinovogo chryasha kolennogo sustava u bol'nyh s gonartrozom. Nauchno-practicheskaya revmatologiya. 2009; 3: 90-3.

8. Tratting S, Ba-Ssalamah A, Pinker K, Plank C, Vescei V, Marlovits S. Magnetic Resonance Imaging. 2005; 23 (7): 779-87.

9. Koval'chul VN. Klassifikaciya povregdeniy chryasha kolennogo sustava. Luchevaya diagnostica, luchevaya terapiya. 2012; 1 : 99-106.

10. Golovaha ML, Loskutov AE, Egorov VF. Korrelyacia dannyh magnitno-rezonansnoy tomografii i artroscopii pri travmaticheskih povregdeniyah kolennogo sustava. Praktikyushemu vrachu. 2011; 12 (2): 99-105.

11. Lazishvili GD, Zatikyan VR, Shukyur-Zadeh ER, Kornaev AS, Akmataliev KI, Danilov MA. Actual direction of chondroplasty. Bulletin of Russian State Medical University. 2013; 3: 13-17.

12. Malyshev EE, Korolyov SB, Pavlov DV, Kuvshinov SG. Osteochondral autoplasty of the extensive post-traumatic defect of the proximal tibia. Modern technologies in medicine. 2014; 6 (2): 142-7.

13. Kotel'nikov GP, Larcev YV, Kudashev DS, Zuev-Ratnikov SD, Shorin IS. Mosaicplasty in the treatment of patients with destructive-dystrophic and post-traumatic lesions hyaline cartilage in the knee joint - experimental and clinical aspects. Fundamental research. 2013; 9: 252-5.

14. Zakirova AR. Artroskopicheskoe lechenie hrjashevyh defectov kolennogo sustava. M.: 2010.

15. Caldwell PE, Shelton WR. Indications for allografts. Orthop Clin North Am. 2005; 36 (4): 459-67.
16. Sadlik B, Wiewiorski M. Implantation of a collagen matrix for an AMIC repair during dry arthroscopy. Knee Surg Sports Traumatol Arthrosc. 2015; 23: 2349-52.

17. Gille J, Schuseil E, Wimmer J, et al. Mid-term results of autologus matrix-indused chondrogenesis for treatment of focal cartilage defects in the knee. Knee Surg Sports Traumatol Arthrosc. 2010; 18: 1456. https://doi.org/10.1007/s00167-010-1042-3.

18. Pascarella A, Ciatti R, Pascarella F, et al. Treatment of articular cartilage lesions of the knee joint using a modified AMIC technique. Knee Surg Sports Traumatol. Arthrosc. 2010; 18: 509-13.

19. Anders S, Wiech O, Schaumburger J, et al. Autologus Matrix induced chondrogenesis (AMIC) for focal chondal defects of the knee - first results. J Bone Jt Surg (Brit.). 2009; 91 (suppl.1): 834.

20. Hangody L, Vasarhelyi G, Hangody LR, et al. Autologus osteochondral grafting technique and long-term results. Injury. 2008; 39 (suppl.1): 32-9.

21. Steinwachs $M$, Kreuz PC. Autologus chondrocyte implantation in chondral defects of the knee with a type I/III collagen membrane: A prospective study with a 3-year follow-up. Arthroscopy. 2007; 23: 381-7.

22. Garkavi AV, Blokov MY. Artroscopicheskaya chondroplastika lokal'nych chryashevyh defectov kolennogo sustava s ispol'zovaniem kollagenovoy membrany CHONDRO-GIDE. Kafedra travmatologii i ortopedii. 2015; 3 (15): 4-7.

23. Jacob RP. AMIC technique for cartilage repair, a single-step surgical intervention as compared to other methods. Eur Cell Mater. 2006; 12 (suppl.1): 26-32.

24. Kramer J, Bohrnsen F, Lindner $U$, et al. In vivo matrix-guided human mesenchymal stem cells. Cell Mol Life Sci. 2006; 63 (5): 616-26. 